\title{
7. Dispossession is a Legitimate Experience
}

\author{
Peter Read
}

This is a legitimate Aboriginal experience to be dispossessed, to be lately impacted, to be pale-skinned, these are legitimate things.

- Shane Smithers ${ }^{1}$

Darug people, that is, the Aboriginal clans of Sydney's west, claim that they are entitled to the privileges and responsibilities that derive from their clear heritage of Aboriginal descent. They assert that they have always been so entitled, the more so since they formed themselves into two corporations. These are the Darug Custodians Aboriginal Corporation, and the Darug Tribal Elders. ${ }^{2}$ Since becoming incorporated in 1997, the two Darug groups meet regularly for social functions, offer Welcomes to Country, produce books and maintain a vigorous cultural centre. ${ }^{3}$ They cannot, however, form another Local Aboriginal Land Council because, under the terms of the Aboriginal Land Rights Act 1983 (NSW), only one Land Council is allowed to represent each area.

Yet their claims to recognition were, and continue to be, opposed by other Aboriginal bodies already constituted under the Aboriginal Land Rights Act. One of these challengers is the existing Darug Local Aboriginal Land Council (LALC), formed soon after the Act, but which, significantly, had changed its name from the Darug to the Deerubbin LALC in 1996. The newly renamed Deerubbin Land Council asserted its right under the Act to represent all Aboriginal people living in the area, irrespective of their place of origin. In 2012, its website claimed to support 'genuine assertions and respectful recognition of traditional ownership (and formal recognition of native title) wherever they occur'. Then followed the caveat:

\footnotetext{
1 Shane Smithers, 'The history of the west', [video interview, historyofaboriginalsydney.edu.au (henceforth HOAS)].

2 Kohen's meeting served as a catalyst that promoted Darug families to seek formal recognition. Many families had already accelerated interest in their own family history in the previous decade. See Gordon Workman, 'We've been invaded twice', [video interview, HOAS].

3 For example, Tobin 2002. A remarkable book produced from the Dharawal Sydney region, is $D^{\prime} h a r a w a l$ Climate and Resources (Bodkin and Robertson 2013).
} 
Deerubbin LALC [Local Aboriginal Land Council] is skeptical, however, that there are Aboriginal people alive who credibly lay claim to traditional ownership of the area. ${ }^{4}$

Such an assertion may seem surprising, since it was in Darug country that Governor Macquarie established the first Aboriginal school, the Native Institution, in 1814. It was in Darug country that he awarded the first Land Grant, supposedly in perpetuity, to a Darug man (Colbee) and to a woman (his sister Maria). The Darug were granted one of New South Wales' earliest reserves, to be shared with Darkinjung people, and established by the Aborigines Protection Board at Sackville Reach on the Hawkesbury River in $1889 .^{5}$

The position of Darug people was trenchantly put by the Gai-Mariagal scholar Dennis Foley in his article, 'What has Native Title done to the Urban Koori in New South Wales who is also a Traditional Custodian? ${ }^{6}$ He wrote that:

[LALCs] were often [formed] without any involvement or consent from local Aboriginal people who were direct descendants of the traditional people of the lands in question. Guringah [a northern Sydney coastal] people generally were still recovering from wearing the brunt of nearly 180 years of physical and psychological trauma (dating from the establishment of Sydney town adjacent to our lands in 1788 through to the 1967 referendum which removed discriminatory clauses from the Australian constitution). These traumas included firstly dispossession of our land, enforced segregation and discrimination, and then assimilation and the denial of our culture. Guringah people were not fully conversant with the new opportunities that the Act bestowed upon them, nor savvy enough about the workings of the new legal system. There was a lag in the granting of these opportunities and in local resolution as to how to respond to them. Another group of Indigenous people however stepped into the vacuum and took advantage of this significant historical event. We Guringah custodians could not believe other Aboriginal people could act against us to both deny our existence and then steal our traditional lands from under us. But they did and history will show that the medium to allow this was the LRA. [Aboriginal Land Rights Act 1983 (NSW) As Amended]. ${ }^{7}$

4 Deerubbin Local Aboriginal Land Council, www.deerubbin.org.au/Final-CLBP-290609.pdf (accessed 
One response to Foley's assertion of denial and theft was made by a researcher for the Federal Court who, assessing evidence for a 2004 Darug Land Claim under the Act, found 'little to suggest on-going traditional values and practices, other than a strong sense of kinship bolstered by a practical reliance upon each others' support' ${ }^{8}$ A second response was made by the Indigenous scholar Suzanne Ingram in her article 'Sleight of Hand: Aboriginality and the Education Pathway'. ${ }^{9}$ Here she argued that the Darug Sydney custodians were 'noticeably absent throughout' the 'highly active and visible period of the Aboriginal movement' of the 1920s and 1930s. They 'have no actual Indigenous reference point'. Seized with a desire to 'belong' analogous to the much discussed European Australian spiritual quest in the 1980s and 1990s, she claimed that the Darug had no strong sense of culture or togetherness comparable to that of the La Perouse community. ${ }^{10}$ This was an argument similar to the contentious dismissal by Justice Olney on the Native Title claim of the Yorta Yorta people of Victoria. The tide of history, he wrote in the late 1990s,

has washed away any real acknowledgment of their traditional laws and any real observance of their traditional customs. The foundation of the claim to native title in relation to the land previously occupied by those ancestors having disappeared, the native-title rights and interests previously enjoyed are not capable of revival. This conclusion effectively resolves the application for a determination of Native Title. ${ }^{11}$

Several scholars have noted what they see in Olney as an unwarranted privileging of the written word over the oral. ${ }^{12}$ Given that so much of the Darug's claim to custodianship is based on oral evidence, it seems pertinent to present a little of it here. It is not the point of this article to argue one side or the other of what seems to be less an Aboriginal historical argument but rather one deeply entangled in the contemporary politics of self-representation. Rather I propose to embrace the historian's task, which is to contextualise and explain the social context of any period under discussion, upon which basis non-specialists may then form their own judgements. Needless to say, the European colonisers' persecution of Aboriginal people was not directed at the Darug alone. I do not seek here to represent the historical context of only those who, like the Darug, demand recognition as Sydney's Indigenous custodians. Aboriginal people from the bush who came to the inner city were treated as harshly if they bore obvious Aboriginal features. The Redfern race riots of the 1970s, in which of course some Sydney traditional custodians also took part, revealed that police brutality and

8 Ward 2001: 7; Quoted by Ingram 2008: 14; See Gale v Minister for Land and Water Conservation (NSW) [2004] FCA 374 (31 March 2004), Madgwick J.

9 Ingram 2008.

10 Ingram 2008: 8.

11 Yorta Yorta Aboriginal Community v Victoria [1998] FCA 1606 (18 December 1998), Olney J., at [129].

12 Furphy 2013: 192. 
injustice, encouraged by the state government, could be worse again than the casual but bitter hurts endured daily at Parramatta or the Hawkesbury half a century earlier.

In presenting the context in which this cultural loss occurred, I shall advance very many instances, drawn from research by the team producing the website historyofaboriginalsydney.edu.au, that will outline some of the reasons why Aboriginal people in Sydney had very good reason not necessarily to extinguish their identity, but to take it 'underground'. Indigenous descent sometimes became a secret shared only by the immediate family or Aboriginal neighbours. ${ }^{13}$

While it is true that Darug people had little part in the confrontations with state authority in the 1920s and 1930s, there were good reasons for their not having been in a position to do so. Much of the traditional teaching has been lost. Like most southern Australian languages, the Darug language has also been effectively lost (though possibly capable of revival). Many formal or collective cultural practices, such as renewal or initiation ceremonies, ceased many years ago, though some have been re-enacted. Creation stories generally lack precise geographical detail. These positions are not much disputed. Tracy Howie, President of the 2010 Guringai Tribal Elders, expressed her despair at the planned attempted obliteration of her people:

That's another difficulty with Native Title in New South Wales. We were the hardest hit. They came in and they either killed us, or they bred it out of us or they disease-riddened us. And all of our culture, all of our language, was outlawed. It became illegal ... so how can we therefore prove native title, when, had our ancestors done that, we wouldn't be alive today? Native Title law contradicts itself ... When people say 'stolen generations', and not taking anything away from the people who were removed from their families, but it goes deeper than just the removal of a person, of a body, but it was the removal of our culture, our song, the removal of our dance our language, everything, it was all stolen. Not just the children. Everything. ${ }^{14}$

To map the historical context, we need some signposts to Sydney's urban history. First, like other parts of Australia, Sydney Aboriginal people have occupied every point on that spectrum of self-identification that has changed from one generation to the next. Today, one can first recognise a category of those who denied their identity for so long that it is now quite forgotten and cannot be revived. Others know of their part-Indigenous descent but have no intention of exploring or revealing it. There are those who recently discovered a concealed identity and embraced it. There are those who are still reticent about an openly

13 Dennis Foley, 'From Redfern to Chester Hill', historyofaboriginalsydney.edu.au [website HOAS]

14 Tracy Howie, 'It's not easy claiming Native Title in NSW', [video interview, HOAS]. 
declared identity, but whose children openly and proudly do so. There are Sydney people, including many Darug, who have for two centuries lived as Aborigines, known their genealogy, and openly and fiercely associated with each other.

Video available online: press.anu.edu.au/titles/aboriginal-history-monographs/longhistory-deep-time/.

\section{Richard Green, 'My family history'}

Source: historyofaboriginalsydney.edu.au.

Secondly, working class areas like Balmain, Glebe and Brooklyn were areas of great ethnic diversity in which Aboriginality, or any other ethnicity, simply was not thought to be important. Many older people testify to this: the Dharawal (south-eastern coastal) woman Margaret Slowgrove, growing up in Botany in the 1940s, knew of her descent, but an identity as one belonging to any ethnicity in particular was irrelevant in a dockside community that included Malays, Maori, Chinese, South Sea Islanders and Filipinos. But the new western suburbs after World War Two were much more homogeneous. Confessing one's Aboriginal inheritance invited trouble. It was here in the west that Aborigines formed a secret army of knowledge holders. The Gai-Mariagal (Camaraigal people, northern Sydney coastal) man Dennis Foley spent some of his teenage years in Fairfield, western Sydney, in the 1960s. As he drove around the suburb in 2010 he could identify house after house once occupied by Aboriginal families - as many, in fact, as made up a typical reserve! Few of his neighbours knew their clans or language names. If they did bear any noticeably Aboriginal features, not many openly identified; but identity remained strong among the secret sharers.

Video available online: press.anu.edu.au/titles/aboriginal-history-monographs/longhistory-deep-time/.

\section{Dennis Foley, 'From Redfern to Chester Hill'}

Source: historyofaboriginalsydney.edu.au.

The government station at La Perouse, as Ingram suggested, presented a telling contrast. That reserve, while mainly composed today of people with links to the south coast, has always contained a mix of different peoples dating from its establishment in 1883 as a holding-paddock for people removed from other areas of Sydney like Circular Quay. On the station, they were subjected to a book full of punitive rules, presided over by a manager, regulating entry and egress, card playing, drinking, tidiness and general submission to White authority. The effect, ironically, was to drive people together psychologically. Disparate though they were, the manager's strictures acted to forge a common identity not of families or clans, but of 'Aborigines'. To observe the shift towards a group identity in process, consider this exchange reported by the manager of another large government reserve, Warangesda, in Wiradjuri country. 
There was another bother with MRS SWIFT today. She openly accuses FANNY HELAND of being enceinte [pregnant] \& told the girls in the Dorm they ought all to laugh at her \& while she was at the washtub yesterday called her a sulky looking pig. FANNY came \& told manager this AM \& when she spoke to MRS SWIFT she said it was all false, that she did not use any such expression. The manager asked her if she had ever said of NANCY MURRAY that she was a Chinese looking thing. Which she indignantly denied but Buckley said he heard her use the expression and FANNY HELAND says she heard her call NANCY a yellow Chinaman. And called the manager a hypocrite and that all the whites were a lot of hypocrites. After the bother MRS SWIFT poked her tongue at Fanny and made faces at her. NANCY MURRAY says she said to the girls in the Dorm she would put the people against the manager, $\&$ as far as the manager has been able to find out has not done so. ${ }^{15}$

The extract shows the ready potential for a quarrel to escalate into an 'us against them' mentality that served to reinforce identity through a consciousness of difference. Thus the imposition of salaried managers and punitive regulations on reserves like La Perouse served only to heighten resentment of the Whites through a strong and developing collective identity. Other Sydney Aboriginal people were ironically, in this sense, not to have had such punitive unity imposed on them. It was only as individuals and families that they endured, for more than two centuries, the daily insults, challenges and punishments for openly asserting their Indigenous heritage. Even if they wanted to, La Perouse residents could never carry their descent underground.

Lastly, identities are often plural. Children who formed themselves into gangs were often Aboriginal and Irish, Aboriginal and Catholic, or from a particular street, family or sports team. Siblings formed gangs to fight other gangs; it was only after their teens that they realised 'we were seen as an Aboriginal gang, but to us, we were just family'. ${ }^{16}$

\section{Living together brought trouble}

Managed reserves were created by government; after 1883, by the NSW Aborigines Protection (later Welfare) Board. There was only one such reserve in Sydney - La Perouse, holding few residents, compared to the newcomers gathering in inner city suburbs after 1900. Like the Darug in Sydney's west,

15 Warangesda Manager's Mission Diary, 7 June 1894, typescript in National Library of Australia; quoted in Read 2000: 55.

16 Peter Radoll, 'My uncles gave me complete freedom', [video interview, HOAS]; McGrath, 2010. 
they rented houses; those who could not built humpies in Yarra Bay or Glebe. In the west, those who could not or did not rent often gathered in Town Camps. People who could not rent, or chose to live with their own mob, took residence in such camps, often sited near water. Such was 'Blacktown Road', an empty paddock near Freeman's Reach, Hawkesbury River, occupied till about 1910.17

The biggest town camps shared by Darug people included Sackville, established as an unmanaged reserve in 1889, and Plumpton, close to the old Blacktown Institution site, on land owned by the Darug identity William Locke. Locke allowed his farming block to be used from about 1903 as an area for his relatives' cottages and humpies, a base for Aboriginal Inland Mission activities, and a Welfare Board ration distribution point. ${ }^{18}$ But living together in poverty was unhealthy; in Plumpton in 1908, two children died of influenza after heavy rains.

More sinisterly, town camps invited the pernicious attention of welfare authorities. At least six children were removed to private homes or the United Aborigines Mission Home at Bomaderry before 1910. ${ }^{19}$ Threatened and persecuted, the people began to leave. The tin mission church closed in 1910. To re-signify what everyone already knew to be the dangerously impermanent nature of town camps, the remaining members of William Locke's family, and others, were finally evicted from the site in 1920. Where were they to go? Many chose the other large town camp familiar to them, at this time mainly occupied by Gundangara (south-western Sydney) families, just outside Katoomba, called the Gully. Until about 1905, Katoomba had seemed to be a safe town for Aborigines; but as the refugee population of the Gully grew, so in proportion grew hostile Welfare interference. Seven children of the Stubbings family were removed in that year. ${ }^{20}$

By 1958, no less than 27 Aboriginal children had been removed from the Gully. Threats of child removal could be almost as deadly as separation itself. Even in the late 1950s, the Stubbings family was told that if the family did not leave the Gully, the children would be taken. Colin Locke's parents, also ordered by the Katoomba Shire Council to leave the Gully, settled legally in the water catchment area of Blackheath with several related Darug families. 'If the white government car comes,' his mother told him, 'grab your brothers, run into the bush, and don't stop running. ${ }^{\prime 1}$ Nor, like Plumpton, was the Gully secure even for adults. Tolerated for decades by the Whites for the labour force the Aborigines provided at the tourist hotels, hospital, sawmills and abattoirs,

17 Julie Janson and Shane Smithers, 'The people of Blacktown Road', [video interview, HOAS].

18 Johnson 2007: 148-149.

19 One of these children was Ruby Hilda Castles; see 'Laraine Sullivan', in Sobott 2013: 156. Laraine is Mary

Castles' daughter.

20 Johnson 2007: 148, 212.

21 Colin Locke, 'Catchment Kids', [video interview, HOAS]. 
all the dozens of Gully residents were evicted in the years between 1955 and 1957 to make way for a racetrack. Some were forced into trucks and left by the roadside in north Katoomba. Five years later, the racetrack had failed, a costly and ill-advised bungle. Today the former residents have renewed the site as an Aboriginal Declared Place.

Choosing to live away from other Aboriginal people brought new problems, while retaining most of the old. In about 1960, at the age of 15, Diane O'Brien was thrown out of her Granville house by her adopting father after she was raped and made pregnant. To protect her baby from removal, she took refuge in an abandoned car in the Granville tip. Here she lived for several weeks until the welfare authorities caught up with her and informed Diane that to keep her child she must marry the rapist. She consented.

Video available online: press.anu.edu.au/titles/aboriginal-history-monographs/longhistory-deep-time/.

\section{Diane O'Brien, 'Adopted, Raped and Pregnant'}

Source: historyofaboriginalsydney.edu.au.

Dennis Foley recalls two older cousins in the same school as he in Chester Hill, western Sydney. One afternoon in the 1950s, the police struck, the children were seized and have never been seen by their extended family again. Was he aware of the possibility of his own removal? 'No, you never thought it would happen to you.' But in the end he was scooped up too. Nearly two years passed before he was able to return. ${ }^{22}$ Removed in about 1952 with his siblings from their tent, concealed on a creek near Berowra, Robert Kitchener reflected after years spent in institutions, 'White was right. That's what they wanted. They wanted us to have another identity.' ${ }^{23}$

Nor did choosing or being forced to move from a town camp by any means guarantee family security. Colin Locke's family had gone from the Blackheath catchment by 1969. In the same decade, Janny Ely and Judy Chester, two Wiradjuri-born youngsters were living in Salt Pan Creek, Georges River. 'Pepper-potted' (that is, allotted a house surrounded by non-Aboriginal neighbours) in a Housing Commission cottage in Green Valley, they discovered that some other residents of the street had taken up a petition to get rid of the newcomers (the petition failed). Ely was forced to hide below the windows of the Green Valley home when the Welfare Officer was out looking for her. ${ }^{24}$

22 Dennis Foley, 'Children Removed from Chester Hill Primary School', [video interview, HOAS].

23 Robert Kitchener, 'What amazes me is that anyone can lock you up on the grounds of your culture', [video interview, HOAS].

24 Judy Chester and Janny Ely, 'Get those blacks out of Green Valley', 'High School and the Welfare', [video interviews, HOAS]. 


\section{Don't be conspicuous}

Learning language was difficult and invited trouble. Frances Bodkin recalls speaking Dharawal at home only when the blinds were drawn at night. ${ }^{25}$ Carol Cooper believes that her parents at Katoomba were ordered never to lock their doors so that the police could enter at any time to check if English was being spoken. ${ }^{26}$ June McGrath, who in 2012 was the President of Link Up Aboriginal Corporation, grew up in Bexley. All her life, she was put down by her sisters for 'daring' to identify as Aboriginal. ${ }^{27}$ As a child in Brisbane, Pat Eatock was ordered to play on the other side of the divided school playground after her father, of obviously Aboriginal descent, came to visit the school. Twenty-five years later, living in a Housing Commission house in Mt Pritchard, near Liverpool, she casually revealed her Indigenous descent to her neighbour, who promptly told her to leave the house, refusing permission for her own son to continue to play with Eatock's. ${ }^{28}$ Karen Maber, of Dharawal descent, worked in her primary school in Kogarah just hard enough to keep herself in the middle of the class roll, and sat as far out of sight as possible, at the back. 'I really loved school. But I didn't want to come first in anything. Too much attention ... I would rather not do well or I'd have to go up to get a certificate.' She kept her Aboriginality to herself until the class, watching a documentary, accused the filmed Aborigines of cruelty. Upset, she confided her identity to her teacher. 'Don't worry dear,' was the reply, 'Nobody will know.' Karen carries the hurt to this day. ${ }^{29}$ Peter Radoll received a hard time from both teachers and other boys at Colyton High School after he received his first Aboriginal Studies Grant cheque in the 1980s. ${ }^{30}$ His mother, at length acquiring loan funds from the western Sydney Foundation for Aboriginal Affairs to buy a house, entered the Bank of New South Wales at St Mary's to transfer the purchase funds to her account, only to find the manager refused to allow the procedure - she could not be Aboriginal, he declared, she was not dark enough. ${ }^{31}$ Carol Cooper and John Mulvay both received much hostility from their teachers in Katoomba; this was worsened, Mulvay reflected, by his family's noticeable poverty. ${ }^{32}$ For 150 years, in north coastal Sydney, the Guringai children of Matora, first wife to Macquarie's friend Bungaree, lived in and around Marra Marra Creek. In 1910, six closely related families lived in Shuttle Bay, at the mouth of the creek. Surrounded by people of many ethnicities they lived as all the others - in fishing, water services and

25 Frances Bodkin, 'I was told we spoke Spanish', [video interview, HOAS].

26 Johnson 2007: 121.

27 June McGrath, 'I'm so proud', [video interview, HOAS].

28 Pat Eatock, 'We never spoke again', [video interview, HOAS].

29 Karen Maber, 'Memories of Kogarah Primary School I', [video interview, HOAS].

30 Peter Radoll, 'It was here that I realised I was different', [video interview, HOAS]

31 Peter Radoll, 'The downside of owning an Aboriginal house', [video interview, HOAS].

32 John Mulvay, 'School was pretty horrific', [video interview, HOAS]. 
local labour. In a waterside area of very diverse ethnic heritage, Aboriginality didn't seem to matter much; except to the police. These families too kept their identity to themselves; any overt display of Aboriginality would have promptly caused the health authorities to find a reason to move them on. Dennis Foley's uncles, he recalled, could fish all day with a rod or line in the Terrigal lagoon. But as fast as an Indigenous fishing spear appeared, so did someone to prevent its use or to move the fishermen on. The historian of the Gully, Dianne Johnson, observed the maxim that has guided Aboriginal people in all of Sydney, and much of Australia: 'The need for most of them to blend in, accompanied by their reluctance to put themselves forward unduly, is still paramount. These are survival skills instilled in them with childhood.' ${ }^{33}$

\section{Aboriginality is shameful}

Pam Young has worked proudly for many Aboriginal organisations. But as a child she describes herself as a 'little shame job'.

[She] used to walk under the water drains to the city and go and get the groceries at Woolworths and Waltons, always walking, come back, go under the water drains and walk to my [adopted] parents' place. It was safer for me to do that because I was so ashamed of my colour and my identity. ${ }^{34}$

Today it takes equal courage to admit one's descent, especially if that descent has been obscured by older family members. Not everyone in a family may choose to identify, even within the same generation. Chris Tobin's mother discovered late in her life that some of those that she had been raised to think of as friends, were actually cousins. Tobin, now in his 30s, revealed how much determination it still takes to declare oneself an Aborigine.

It's a matter of keeping quiet so your kids don't get taken, we were told the reason why we were so dark was that we were Spanish. [We were told] [w]e've got Aboriginal blood, but we're not Aboriginals. Aboriginal people were smelly, untrustworthy, unclean kind of people, that there was Spanish in the family, and there's members of the family [now] who do not want to know that. It's a lot like how people treat you as well. People need to be encouraged, and I get that people don't put their hand up to say they're Aboriginal, I really do, gosh, who wants an argument. You can tell [people] you're Macedonian, you tell them you're Croatian

33 Johnson 2007: 151

34 Pamela Young, 'No more a little shame job', [video interview, HOAS]. 
or whatever, no one's going to give you an argument, but gosh you tell someone you're Aboriginal: 'No you're not!' Jesus - all right, well. So I certainly think the generation before us, they don't want to have that argument with their friends thank you very much, so they just keep quiet. I love that today in our world ... that you can proudly be an Aboriginal person, the Darug community's very accepting, that's a huge step I think. ${ }^{35}$

Several odd results have flowed from maintaining a surreptitious identity. Clearly, it can be kept underground for so long that finally everyone forgets it was ever there. Today's Darug sometimes challenge the identity of others, 'Oh, we never heard of her when I was a kid', unaware that these unrelated families may have adopted the same survival practices as themselves in taking their Indigenous descent underground. And today, in circumstances less difficult (as far as recognition by non-Aboriginal people is concerned) an almost forgotten identity can be rediscovered, and embraced. Bob Waterer, another descendant of Matora Bungaree, and now in his mid-80s, explained that the few hints he received as child of his Aboriginal descent he had been quite willing to discountenance. ${ }^{36}$ Only after his sister's death did documents, coinciding with the publication of a book of Hawkesbury River history, reveal to him his Guringai descent. All his life he had lived comfortably as a non-Aboriginal. But now, openly declaring his new-found identity, he was surprised and gratified to be greeted warmly both by well-intentioned Whites, and even by members of the non-local Aboriginal community who had seen themselves as caretaker-custodians until the actual Guringai could recover, or declare themselves. ${ }^{37}$ What, perhaps Waterer could not understand because he had never experienced life as a declared Aborigine, were the everyday insults and necessary concealments that he had escaped all his life. No doubt his mother had very well understood the consequences of open identification, even if Waterer himself did not.

The costs of concealment have been heavy for many. Shane Smithers, descended from the Blacktown Road mob, insists on the historical circumstances of the loss of cultural practices:

Not so in the west [of Sydney], where disease and fighting very quickly decimated the communities ... This is a legitimate Aboriginal experience to be dispossessed, to be lately impacted, to be pale-skinned, these are legitimate things. Doesn't make me less Aboriginal than anybody else.

35 Chris Tobin, 'It takes a lot of courage to identify', [video interview, HOAS].

36 Bob Waterer, 'I wasn't very interested in it in my younger days', [video interview, HOAS].

37 Susan Moylan-Coombs, 'I feel very connected to this country', [video interview, HOAS]. 
It robs me of my identity because I don't have that same richness of culture that you find in the [Northern] Territory ... The language has been lost, I don't know any Darug words. ${ }^{38}$

Smithers' cousin Julie Janson, having been certain of but unable to pinpoint her Darug descent, at length tracked her family's town camp to the same Blacktown Road town camp. Her father, probably for mixed motives, chose to deny this (rather obvious) descent. After finally confirming, through research, what she had suspected all her life, Janson related her story to a class she was teaching. The next time she entered the classroom she heard a voice at the back of the room stage-whispering 'boong ... boong ... boong'. She reflected:

Ah, that's what my father and my family's secret saved me from putting up with. Unlike Aboriginal people who all their lives had suffered and been discriminated against, I grew up thinking I could do anything in the world, and I was anybody, go to university, get a great result, get a couple of degrees, become a writer, anything I wanted, because no one was putting me down. And I realised that in a way that this was a kind of a gift. But it's so hard that that racism stopped my dad and my grandmother from being able to acknowledge their Darug roots from being able to acknowledge that they were Aboriginal. ${ }^{39}$

Living as an Aborigine was never a picnic at St Marys, or Parramatta, or Windsor. It has never been easy declaring and living an urban identity, then or now. It went hard on everybody. Yet perhaps it was worse for the self-styled traditional custodians of the wider Sydney region who, like Colin Workman, maintain:

We were the only nation to have been invaded twice ... First by Cook when he got here, second by the Indigenous people of the rest of Australia. ${ }^{40}$

\section{Bibliography}

\section{History of Aboriginal Sydney}

Bodkin, Frances, 'I was told we spoke Spanish' [video interview, historyofaboriginalsydney.edu.au].

Chester, Judy and Janny Ely, 'Get those blacks out of Green Valley', 'High School and the Welfare', [video interviews, historyofaboriginalsydney.edu.au].

38 Shane Smithers, 'The history of the west', [video interview, HOAS]

39 Julie Janson, 'My father's secret', [video interview, HOAS].

40 Colin Workman, 'We were invaded twice', [video interview, HOAS]. 
Eatock, Pat, 'We never spoke again', [video interview, historyofaboriginalsydney. edu.au].

Foley, Dennis, 'From Redfern to Chester Hill', [video interview, historyofaboriginalsydney.edu.au].

Foley, Dennis, 'Children Removed from Chester Hill Primary School', [video interview, historyofaboriginalsydney.edu.au].

Howie, Tracy, 'It's not easy claiming Native Title in NSW', [video interview, historyofaboriginalsydney.edu.au].

Janson, Julie, 'My father's secret', [video interview, historyofaboriginalsydney. edu.au].

Janson, Julie and Shane Smithers, 'The people of Blacktown Road', [video interview, historyofaboriginalsydney.edu.au].

Kitchener, Robert, 'What amazes me is that anyone can lock you up on the grounds of your culture', [video interview, historyofaboriginalsydney.edu.au].

Locke, Colin, 'Catchment Kids', [video interview, historyofaboriginalsydney. edu.au].

Maber, Karen, 'Memories of Kogarah Primary School' [video interview, historyofaboriginalsydney.edu.au].

McGrath, June, 'I'm so proud', [video interview, historyofaboriginalsydney. edu.au].

Moylan-Coombs, Susan, 'I feel very connected to this country', [video interview, historyofaboriginalsydney.edu.au].

Mulvay, John, 'School was pretty horrific', [video interview, historyofaboriginalsydney.edu.au].

O'Brien, Diane, 'Adopted, Raped and Pregnant', [video interview, historyofaboriginalsydney.edu.au].

Radoll, Peter, 'My uncles gave me complete freedom', [video interview, historyofaboriginalsydney.edu.au].

Smithers, Shane, 'The history of the west', [video interview, historyofaboriginalsydney.edu.au]

Waterer, Bob, 'I wasn't very interested in it in my younger days', [video interview, historyofaboriginalsydney.edu.au]. 
Workman, Gordon, 'We've been invaded twice', [video interview, historyofaboriginalsydney.edu.au].

Young, Pamela, 'No more a little shame job', [video interview, historyofaboriginalsydney.edu.au].

\section{Other sources}

Bodkin, Frances (compiler) and Lorraine Robertson (illustrator) 2013, D'harawal Climate and Resources, Envirobooks, Sussex Inlet.

Brook, Jack 1999, Shut out from the World: The Sackville Aborigines Reserve and Mission, 1989-1946, Deerubbin Press, Seven Hills.

Foley, Dennis 2007, 'What has Native Title done to the urban Koori in New South Wales who is also a Traditional Custodian', in Benjamin R Smith and Frances Murphy (eds), The Social Effects of Native Title Recognition, Translation, Coexistence, Centre for Aboriginal Economic Policy Research Monograph No. 27, ANU E Press, Canberra, 166-179.

Furphy, Samuel 2013, Edward M. Curr and the Tide of History, Aboriginal History Monograph 26, ANU E Press, Canberra.

Ingram, S 2008, 'Sleight of Hand: Aboriginality and the Education Pathway', paper delivered to World Indigenous Peoples Conference on Education, Melbourne.

Johnson, Diane 2007, Sacred Waters: The Story of the Blue Mountains Gully Traditional Owners, Halstead, Sydney.

McGrath, Ann, 2010, 'Shamrock Aborigines: the Irish, the Aboriginal Australians and their children', Aboriginal History: 34: 55-84.

Members of the Aboriginal Community 1987, La Perouse: The Place, the People and the Sea, Aboriginal Studies Press, Canberra.

Read, Peter 2000, 'Freedom and control on the southern institutions, New South Wales, 1879-1909', in Peter Read (ed.), Settlement: A History of Australian Indigenous Housing, Aboriginal Studies Press, Canberra.

Sobott, Gaele (ed.) 2013, Young Days: Bankstown Elders Oral History Project, BYDS, Bankstown.

Tobin, Colin 2002, The Dharug Story, An Aboriginal History of Western Sydney from 1788, fifth edition, Chris Tobin, Glenbrook, New South Wales.

Ward, A 2001, 'Gale for Darug Native Title Claim in Western Sydney', Report to the Federal Court of Australia: New South Wales District Registry. 
This text is taken from Long History, Deep Time: Deepening Histories of Place, edited by Ann McGrath and Mary Anne Jebb, published 2015 by ANU Press, The Australian National University, Canberra, Australia. 